\title{
Effect of Climate Change on Soil Chemical and Biological Properties-A Review
}

\author{
M.C. Anjali ${ }^{* *}$ and B.C. Dhananjaya ${ }^{2}$
}

Department of Soil Science and Agricultural Chemistry, UAHS, Shivamogga-577225, India

*Corresponding author

\begin{abstract}
A B S T R A C T
Keywords

Climate, Soil

Properties, $\mathrm{CO}_{2}$

Article Info

Accepted:

12 January 2019

Available Online:

10 February 2019

Climate change influences composite set of measurable physical, chemical and biological soil properties attributes which relate to functional soil processes. Climate change impacts soil chemical, physical and biological functions through a range of predicted global change drivers such as rising atmospheric carbon dioxide $\left(\mathrm{CO}_{2}\right)$ levels, elevated temperature, altered precipitation (rainfall) and atmospheric nitrogen $(\mathrm{N})$ deposition (French et al., 2009). The exact direction and magnitude of these impacts will be dependent on the amount of change in atmospheric gases, temperature, and precipitation amounts and patterns. Many studies have progressed our understanding of relationships between particular soil properties and climate change drivers, e.g. responses to temperature, $\mathrm{CO}_{2}$ or rainfall. The complexity and interdependence of many of the climate change drivers influence soil microbial properties like microbial biomass and biomass diversity, rate of organic matter decomposition, $\mathrm{C}$ and $\mathrm{N}$ cycles, chemical properties of soil like $\mathrm{pH}, \mathrm{EC}$, nutrient availability and physical properties like porosity, aggregate stability, soil erosion, etc.
\end{abstract}

\section{Introduction}

The most recent report of the Intergovernmental Panel on Climate Change (IPCC) indicates that the average global temperature will probably rise between 1.1 and $6.4^{\circ} \mathrm{C}$ by $2090-2099$, as compared to 1980-1999 temperatures, with the most likely rise being between 1.8 and $4.0^{\circ} \mathrm{C}$ (IPCC, 2007). The idea that the Earth's climate is changing is now almost universally accepted in the scientific community (Cooney, 2010; Corfee- Morlot et al., 2007), and even many scientists who dispute that climate change is anthropogenic are in agreement that it is happening (i.e., Kutílek, 2011; Carter, 2007; Bluemle et al., 1999). Therefore, even if we can't agree on why climate change is happening, it should be possible to agree that it is happening, and with climate change happening, there will be effects on the environment, including the soil. In the last century considerable changes took place in the gas composition of the atmosphere due to natural processes and human activities, such as increasing energy consumption, industrialization, and intensive agriculture, urban and rural development. This has led to a 
rise in global temperature and high spatial and temporal variability. The changing the temperature regime would result in considerable changes in the precipitation pattern. Soils are intricately linked to the atmospheric-climate system through the carbon, nitrogen, and hydrologic cycles.

\section{Factors of soil formation}

Soil is a naturally occurring body, that has been evolved owing to combined influence of climate and organisms acting on parent material as conditioned by topography over a period of time. Living things: Plant roots physically break rocks into small pieces; lichen dissolves rock; burrowing animals mix the soil and help aeration. Climate: heat and water accelerate chemical changes (so moist, temperate areas have different soils than arid, tropical, or polar areas). Topography: Loose soil stays in place in flat areas, allowing more thorough physical and chemical alteration of its grains. On steep slopes, the soil moves downhill before complete alteration can occur. Parent material: Chemical changes during soil formation depend on what minerals and rocks are present. Ex: Calciumrich soils generally form from calcium-rich rocks (like limestone) but not from calciumpoor rocks like granite. Time: When bedrock is exposed at the surface, chemical, biologic, and physical processes combine to produce a thin soil layer.

Over time, the processes extend vertically downward, developing soil horizons whose position and thickness change over time. Climate is the average weather at a given point and time of year over a long period. The average weather includes all the associated features such as temperature, wind patterns and precipitation. Any change in climate over time, whether due to natural variability or as a result of human activity is called as climate change. Climate change and its hydrological consequences may result in the significant Modification of soil conditions. The impact analysis of potential future changes is Rather difficult, due to the uncertainties in the forecast of global and long-term Temperature and precipitation patterns (including their spatial and temporal variability) Combined here with the changing hydrological cycle and the complex and integrated Influences of natural vegetation and land use pattern (partly due to the changes in the Socio-economic conditions). Consequently the long-term and global 'soil change Prognosis' can only be a rather rough, sometimes imaginative estimation and allows only for the drawing of general conclusions. In the natural soil formation processes the pedogenic inertia will cause different Time-lags and response rates for different soil types developed in various regions of our Globe (Scharpenseel et al., 1990; Lal et al., 1994; Rounsevell and Loveland, 1994).

\section{Drivers of climate change}

Climate change impacts soil chemical, physical and biological functions through a range of predicted global change drivers such as $\mathrm{CO}_{2}, \mathrm{~N}$ deposition, Temperature and Rainfall.

The $\mathrm{CO}_{2}$ concentration reached a level of 386 ppm in 2009 and increased further to 389 ppm. This is an increase of about $110 \mathrm{ppm}$ $(+38 \%)$ compared to the pre-industrial levels (i.e. before 1750) (NOAA, 2011). Atmospheric $\mathrm{CO}_{2}$ concentration increased globally by nearly $30 \%$, Temperature by approximately $0.6^{\circ} \mathrm{C}$, and these trends are projected to continue more rapidly. The suggested increase in mean annual surface temperature of $2-7^{\circ} \mathrm{C}$ by 2100 is the largest change globally. The Nitrous oxide $\left(\mathrm{N}_{2} \mathrm{O}\right)$ concentration in 2009 was 322 ppm, up 0.6 $\mathrm{ppb}$ from the year before (Encyclopedia Britannica). The atmospheric carbon dioxide 
increased in 2012 at a faster rate than the average over the past 10 year because of a combination of continuing growth of emissions and a decreasing in land carbon sinks. The carbon dioxide emissions recorded high in 2012, the emission trend of carbon dioxide by different countries as followed the decreasing order: China $>$ Japan $>$ Middle East $>$ India $>$ European Union $>$ United States. China is the major contributor for carbon dioxide emission. India contributes about 7.7 percent to the total world emission. The carbon dioxide released to the atmosphere is more compare to the carbon sequenced in soil due to human activity and natural processes. The $\mathrm{N}_{2} \mathrm{O}$ enters to the atmosphere through Emitted during agricultural and industrial activities, as well as during burning of fossil fuels and solid waste. The nitrous oxide concentration in the atmosphere increases 19\% above the pre-industrial level. Emission trend of nitrous oxide by different sources as followed the decreasing order: soil $>$ agriculture $>$ rivers $>$ oceans $>$ fossil fuel $=$ biomass $>$ human activity. Soil is the major contributor for nitrous oxide emission. Soils contribute about 6.6 percent to the total emission of nitrous oxide (world energy outlook special report 2012.

According to the Intergovernmental Panel on Climate Change, global temperatures are expected to increase 1.1 to $6.4^{\circ} \mathrm{C}$ during the 21 st century. When the green houses gasses increases in the atmosphere that leads to increases the earth temperature. Some of the infrared radiation passes through the atmosphere and some of the radiation is absorbed and re emitted by the green house gasses molecule. The effect of this warm up the earth surface and lower atmosphere. As average global temperatures rise, the warmer atmosphere can also hold more moisture, about 4 percent more per degree Fahrenheit temperature increase. Thus, when storms occur there is more water vapor available in the atmosphere to fall as rain, snow or hail Worldwide, water vapor over oceans has increased by about 4 percent since 1970 according to the 2007 U.N. Intergovernmental Panel on Climate Change report.

\section{Why should we be interested in climate change?}

Climate determines the type and location of human managed ecosystems, such as agricultural farmlands. Climate affects the weathering of rock, the type of soil that forms, and the rate of soil formation. Climate helps to determine the quantity and quality of water available for human use. Climate determines the severity of droughts, storms, and floods. Climate largely determines the nature and locations of biomes (major terrestrial ecosystems, defined based on their plant communities).

The climate change affect the net primary productivity in interactive effect with land management practices by affecting soil processes like physical, chemical and biological processes (Adapted from Dalal and Moloney, 2000; Gregorich et al., 1994; Haynes, 2008; Idowu et al., 2009; Kinyangi 2007; Reynolds et al., 2009; Stenberg, 1999).

Climate change influences composite set of measurable physical, chemical and biological soil properties attributes which relate to functional soil processes. By considering know I interested to know the impact of climate change on chemical properties of soil

\section{Soil chemical properties affected by the climate change}

Soil $\mathrm{pH}$, Rate of acidification or alkalization, Electrical conductivity, Leachable salts adsorption, CEC, Plant available N,P,K,S. etc., are affected by climate change 
Schematic representation of the potential links between climate change, land use and management change, and soil health indicators (modified from Dalal and Moloney, 2000; French et al., 2009; Karlen et al., 2003; Nuttall, 2007)

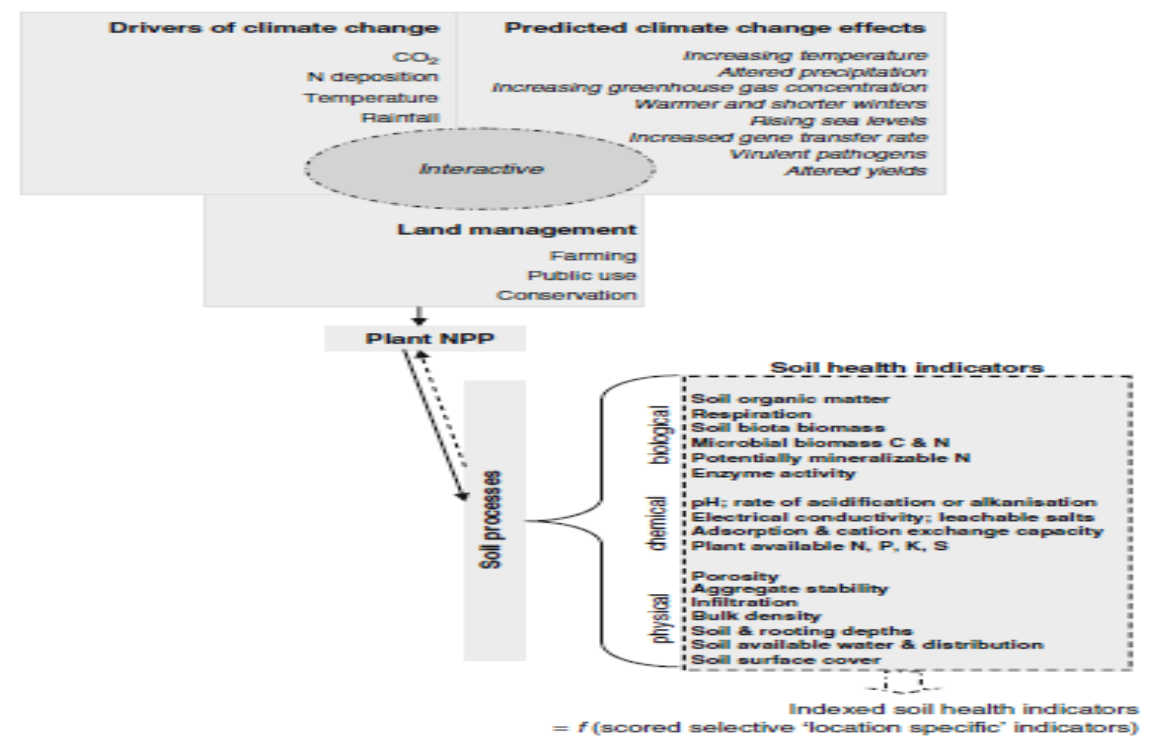

Soil health indicators and relations to processes and functions under projected climate change scenarios

\begin{tabular}{|l|l|}
\hline Soil health indicators & Soil processes affected \\
\hline PHYSICAL & Aggregate stability, organic matter turnover \\
\hline Soil structure & $\begin{array}{l}\text { Air capacity, plant available water capacity, relative yield } \\
\text { capacity }\end{array}$ \\
\hline Porosity & Soil water availability and movement. \\
\hline Infiltration & Soil structural condition, compaction \\
\hline Bulk density & plant available water capacity, sub soil salinity. \\
\hline Soil depth and rooting & $\begin{array}{l}\text { Field capacity, permanent wilting point, macro pores } \\
\text { flow, texture. }\end{array}$ \\
\hline Soil plant available water and distribution & $\begin{array}{l}\text { soil water and nutrient movement, soil stabilization, C } \\
\text { and N fixation }\end{array}$ \\
\hline Soil protective cover & Biological and chemical activity thresholds \\
\hline CHEMICAL AND BIOLOGICAL & Plant and microbial activity thresholds. \\
\hline pH & Plant available nutrients and potential for loss \\
\hline EC & $\begin{array}{l}\text { Plant residue decomposition, organic matter storage and } \\
\text { quality, macro aggregate formation, metabolic activity of } \\
\text { soil organisms, net inorganic N flux from mineralization } \\
\text { and immobilization }\end{array}$ \\
\hline Plant available N, P,K. & C and N mass and balance. \\
\hline $\begin{array}{l}\text { Soil organic matter } \\
\text { light fraction or Macro-organic matter } \\
\text { Mineralisable C and N }\end{array}$ & Microbial activity \\
\hline Soil total C and N & Microbial activity \\
\hline Sol respiration & Substrate use efficiency \\
\hline Microbial biomass C and N & Nutrient cycling and availability \\
\hline Microbial quotients & \\
\hline Microbial diversity &
\end{tabular}




\section{Soil pH}

Brinkman and Sombroek (1999) suggested that most soils would not be subjected to rapid $\mathrm{pH}$ changes resulting from drivers of climate change such as elevated temperatures, $\mathrm{CO}_{2}$ fertilization, variable precipitation and atmospheric $\mathrm{N}$ deposition. Similar findings are founded by DeVries and Breeuwsma (1987); McCarty et al., (2001). Drivers of climate change will affect OM status, C \& nutrient cycling, plant available water \& hence plant productivity, which in turn will affect soil pH (Reth et al., 2005).

They sampled at locations arrayed in an elevation transect up the slope of Rattlesnake mountain $(1093 \mathrm{~m})$ located on the ALE(Arid Land Ecology reserve). Twenty-five sites were identified for sampling starting at an elevation of $228 \mathrm{~m}$ and continuing every $25 \mathrm{~m}$ to a maximum elevation of $844 \mathrm{~m}$. Average precipitation increases from $180 \mathrm{~mm}$ at the lowest elevation to $270 \mathrm{~mm}$ at the $844 \mathrm{~m}$ elevation site. The Soil $\mathrm{pH}$ decreased with increasing elevation, the trends of decreasing soil $\mathrm{pH}$ could be due to increased leaching of basic cations in the higher elevations from greater precipitation and from increased nitrification. Therefore the $\mathrm{pH}$ of soil decreases when move from lower elevation to higher elevation as shown in the Figure 1 (Smith et al., 2002).

\section{EC}

Pariente (2001) examined the dynamics of soluble salts concentration in soils from four climatic regions (Mediterranean, semi-arid, mildly arid and arid) and found a non-linear relationship between the soluble salts content and rainfall, with sites that received $<200 \mathrm{~mm}$ rainfall contained significantly high soluble contents and vice versa. They sampled at locations arrayed in an elevation transect up the slope of Rattlesnake mountain (1093 m) located on the ALE(Arid Land Ecology reserve. Twenty-five sites were identified for sampling starting at an elevation of $228 \mathrm{~m}$ and continuing every $25 \mathrm{~m}$ to a maximum elevation of $844 \mathrm{~m}$. Average precipitation increases from $180 \mathrm{~mm}$ at the lowest elevation to $270 \mathrm{~mm}$ at the $844 \mathrm{~m}$ elevation site. They reported that soil EC increased with elevation with the top two sites significantly greater than the lower sites The increase in EC with elevation would seem to contradict the hypothesis that the leaching of bases is causing the lower soil $\mathrm{pH}$ values with increasing elevation. However, in both the grass and crust soil there was a significant amount of nitrate in the higher elevations which could contribute to the increase in EC over the $500 \mathrm{~m}$ elevation transect as could greater $\mathrm{H}^{+}$ion concentrations from the lower $\mathrm{pH}$ as shown in Figure 2 (Smith et al., 2002).

\section{CEC}

CEC of coarse-textured soils and low-activity clay soils is attributed to that of SOM, the increasing decomposition and loss of SOM due to elevated temperatures may lead to the loss of CEC of these soils (Davidson and Janssens, 2006). Low CEC of soil may result in increased leaching of base cations in response to high and intense rainfall events, thus transporting alkalinity from soil to waterways.

\section{Acidification}

Decreasing precipitation may reduce downward filtration and leaching. Climate determines the dominant vegetation types, their productivity, the decomposition rate of their litter deposits, and influences soil reaction in this indirect way.

\section{Salinization/Sodification}

A consequence of the expected global 'warming' is the rise of eustatic sea level: increase of inundated territories (especially in 
the densely populated delta regions and river valleys), and the areas under the influence of sea water intrusion.

\section{Plant available nutrients}

Nutrient cycling, especially $\mathrm{N}$, is intimately linked with soil organic $\mathrm{C}$ cycling and hence drivers of climate change such as elevated temperatures, variable precipitation and atmospheric $\mathrm{N}$ deposition are likely to impact on $\mathrm{N}$ cycling and possibly the cycling of other plant available nutrients such as phosphorus and sulphur, etc. (Weil and Magdoff, 2004, Kumar and Swarup, 2012). The soil $\mathrm{N}$ in the surface $5 \mathrm{~cm}$ of the forest soil increased linearly during 5 years of exposure to elevated $\mathrm{CO}_{2}$ as shown in the Figure 3. While $\mathrm{N}$ in the ambient plots remained relatively constant, consistent with vegetative effects on soil formation, increases in soil $\mathrm{N}$ storage, particularly in forests, are more likely to occur near the surface, where inputs from roots and above ground litter are greatest (Jastrow et al., 2005).

The positive feedbacks amplify system responses to changes in constraints. Thus, responses to boreal and temperate forests to carbon dioxide induced climate change may depend on the balance between changes in hydrological cycle that constrain the forest response and the positive feedbacks between the carbon and nitrogen cycles that amplify this response. If the vegetation response to drought decreases nitrogen availability, then the positive feedback between the carbon and the nitrogen cycles weakens, resulting in a decline in productivity. Conversely, if climate change alters forest composition, thus enhancing growth of species which can further enhance soil nitrogen availability through the chemistry of their litter, then the same positive feedback results in an increased productivity. Therefore, interactions between vegetation and water and nitrogen availabilities may produce a bifurcation in the forest ecosystem response that is increased productivity where soil water is not limiting and nitrogen availability is enhanced, decreased productivity where water and nitrogen become more limiting. Forest responses to climate change are as sensitive to the indirect effects of climate and vegetation on soil properties as they are to direct effects of temperature on tree growth. The heterogeneity of landscape, particularly the distribution of various soils, becomes an important factor determining forest responses to climate change, because these bifurcations can occur within as well between, biomes (Paster and Post, 1988).

\section{Biological Properties Affected by Climate Change}

While the chemistry (and physics) of the soil system provides the context... it is the soil biota which is adaptive to changes in environmental circumstances" (Kibblewhite et al., 2008).

\section{Soil microbial biomass}

Soil microbial biomass has been shown to be responsive to short term environmental changes (Haynes, 2008 and Pregitzer et al., 2008). Recent studies revealing significant decline in the soil microbial biomass during long-term simulated climatic warming experiments (Rinnan et al., 2007)

The relative abundance of bacterial phyla was clearly impacted by the precipitation treatment, which led to shifts in the relative abundance Proteobacteria and Acidobacteria. The other two factors, carbon dioxide and temperature, did not have a major impact on the distribution of these groups. The relative abundance of Proteobacteria was greater in the wet relative to the dry treatments, whereas Acidobacteria abundance was greater in dry 
treatment as shown in Figure 4. Because Acidobacteria is ubiquitous phylum in soil they required aerobic condition for their metabolism, Proteobacteria required anaerobic condition for their metabolism (Castro et al., 2009).

\section{Soil respiration}

Soil respiration, particularly its temperature response is widely acknowledged to be a critical link between climate change and the global C cycle (Wixon and Balser, 2009). Studies have also shown that soil respiration is relatively responsive to changes in the seasonal timing of rainfall, which is predicted to change according to global and regional climate models (Chou et al., 2008)

This research was conducted by FACTS-II FACE project is located near Rhinelander, WI, USA $\left(45^{\circ} 40.5^{\prime} \mathrm{N}, 89^{\circ} 37.5^{\prime} \mathrm{E}, 490 \mathrm{~m}\right.$ elevation). The experiment is a randomized complete block design with three replicates of factorial $\mathrm{CO}_{2}$ (ambient and elevated to $560 \mu \mathrm{l}$ $1-1$ ) and $\mathrm{O}_{3}$ (ambient and elevated to $50 \mathrm{nl}$ 1-1) treatments. Seasonal soil respiration for
2005, 2006 and 2007 was significantly greater under $+\mathrm{CO}_{2}$, but was not significantly affected by $+\mathrm{O}_{3}$ (Fig. 5). The $+\mathrm{CO}_{2}+\mathrm{O}_{3}$ treatment tended to have the greatest values for seasonal soil respiration across all community types $\left(5-10 \%\right.$ greater than $\left.+\mathrm{CO}_{2}\right)$, but values for the $+\mathrm{CO}_{2}+\mathrm{O}_{3}$ treatment were not significantly greater than those for $+\mathrm{CO}_{2}$ alone. Across treatments, seasonal soil respiration was significantly greater in the aspen community than for the birch/aspen and maple/aspen communities during 2005 and 2006, but not in 2007 (Pregitzer et al., 2008).

\section{Enzyme activity}

Soil enzyme activities show rapid response to changes in soil management (Aon et al., 2001; Ruiz et al., 2009). Studies of individual enzyme activities report strong temporal \& spatial variability, often leading to conflicting results (Aon et al., 2001; Ruiz et al., 2009). Dorodnikov et al., (2009) showed that by altering the quantity and quality of below ground $\mathrm{C}$ input by plants, elevated $\mathrm{CO}_{2}$ may stimulate microbial enzyme activities (Castor et al., 2009).

Enzyme activities and elevated $\mathrm{CO}_{2}$

\begin{tabular}{|c|c|c|}
\hline Enzyme & Ambient $\mathrm{CO}_{2}\left(\mu \mathrm{mol} \mathrm{kg}{ }^{-1} \mathrm{~h}^{-1}\right)$ & Elevated $\mathrm{CO}_{2}\left(\mu \mathrm{mol} \mathrm{kg}{ }^{-1} \mathrm{~h}^{-1}\right)$ \\
\hline$\alpha-1,4$-glucosidase & $1.0 \pm 0.9$ & $2.1 \pm 0.8$ \\
\hline$\beta-1,4-g l u c o s i d a s e$ & $145.7 \pm 18.6$ & $129.5 \pm 7.8$ \\
\hline Alk phosphatase & $332.4 \pm 6.3$ & $234.8 \pm 7.6$ \\
\hline $\mathrm{N}$-acetylglucosaminidase & $48.0 \pm 2.1$ & 6.7 \\
\hline
\end{tabular}

\section{Potentially mineralizable $\mathbf{C}$ and $\mathbf{N}$}

These processes are closely connected with the soil moisture regime a and with the abiotic $\&$ biotic transformation phenomena (fixation, immobilization / release, mobilization; changes in solubility and redox status, etc.). High precipitation increases leaching, filtration loss (potential groundwater pollution) and reductive processes. Low precipitation (dry conditions) may reduce the solubility, mobility and availability of available elements and compounds. Groffman et al., (2009) reported that the rates of in situ net mineralization and nitrification were increases with soil moisture content in summer (Fig. 6).

The rates of in situ net mineralization and nitrification were faster in summer than in winter and in high elevation plots than in lower elevation plots (Fig. 6). Net nitrification was particularly slow on the lower valley low elevation plot. Winter mineralization activity 
ranged from 14 to $57 \%$ of annual activity in $2002 / 2003$ and $7 \%$ to $23 \%$ of annual activity in 2003/2004 and was faster in high elevation plots. Winter nitrification ranged from 6 to $25 \%$ of annual activity in 2002/2003 and from 0 to $29 \%$ of annual activity in 2003/2004 and was faster in high elevation plots. Summer activity was strongly correlated with soil moisture. In winter, sites with more soil freezing had slower rates of nitrification, but the correlation between maximum soil frost and winter nitrification was not significant. Because there were markedly different amounts of soil frost in the two winters of the study, correlations between soil frost and $\mathrm{N}$ cycling (Groffman et al., 2009).

Castro et al., (2009) reported that potential mineralization and nitrification is more in case of ambient carbon dioxide treatment compare to elevated condition. In both the treatment in the beginning there was decreasing in potential mineralization and nitrification. This is more in ambient condition because of more microbial activity.

\section{Soil organic matter}

Generally, increase in temperature has been reported to enhance SOM decomposition, but rising temperature, precipitation, $\mathrm{CO}_{2}$ fertilization and atmospheric $\mathrm{N}$ deposition may support high plant productivity and OM input to soil and consequently increase SOM. Davidson and Janssens (2006) reported that accessibility and availability of SOM to micro-organisms govern SOM losses rather than rate-modifying climate factor (i.e. temperature). The rate of decomposition is exceeds the rate of humus formation when moving from cold to hot climate. Therefore the amount of humus is low in their profile of soil in hot dry condition (Fig. 7) because of more microbial activity (Brinkman et al., 1990).
A higher biomass production of wild plants as well as more crop residues as a consequence of higher crop yields increases the nutrient offer for soil organisms. Higher soil temperatures also stimulate the activity of soil organisms. Here for, aerated soils of the lower and middle latitudes higher humus contents can be expected. In contrast, in the soils of higher latitudes smaller humus contents will occur. Wet soils with low air content, even in humid tropical areas, will be characterized by increasing humus contents. Higher soil temperatures will also stimulate the activities of aggregate forming and soil mixing animals among the soil organisms, in fact mainly the activities and efficiency of earth worms (Blume, 2011).

The organic $\mathrm{C}$ in the surface $5 \mathrm{~cm}$ of the forest soil increased linearly during 5 years of exposure to elevated $\mathrm{CO}_{2}$, while $\mathrm{C}$ in the ambient plots remained relatively constant. No significant changes in the soil $\mathrm{C}$ were found at deeper depths for either elevated or ambient $\mathrm{CO}_{2}$ as shown in Figure 8. Consistent with vegetative effects on soil formation, increases in soil $\mathrm{C}$ storage, particularly in forests, are more likely to occur near the surface, where inputs from roots and above ground litter are greatest. If we sampled to $15 \mathrm{~cm}$ in one increment, the $\mathrm{C}$ accrued in the surface $5 \mathrm{~cm}$ would have been diluted with the unchanged $\mathrm{C}$ pool at 5 to $15 \mathrm{~cm}$ and we would not have detected a significant change (Jastrow et al., 2005).

The atmospheric carbon dioxide had significant effect on soil properties after 5 years of cropping system but varied for the two different cropping systems, for soil carbon, a significant cropping system by carbon dioxide interaction was noted. In this case, soil carbon was unaffected by elevated $\mathrm{CO}_{2}$ in the sorghum system. In the soybean cropping system, elevated $\mathrm{CO}_{2}$ increased soil carbon significantly as shown in Figure 9. 
Because that $\mathrm{CO}_{2}$ enrichment had more effect on increasing soybean residue compared with sorghum to the soil (Prior et al., 2003). Similarly carbon dioxide increases the soil carbon as reported by Shakiba (2000).

In conclusion, higher temperature speeds up the natural decomposition of $\mathrm{OM}$ and soil degradation processes, accelerate the cycling of carbon, nitrogen, phosphorus, potash \& sulphur in the soil - plant - atmosphere system, Increase the process of nitrogen fixation due greater root development. Higher rainfall Increase the vulnerability to water erosion, leaching rate, causes temporary flooding or water saturation, hence OM decomposition reduces. Lower rainfall increases the vulnerability to wind erosion, Suppress both root growth \& deposition of organic matter and it increases the salt accumulation. Higher $\mathrm{CO}_{2}$ concentration increases the photosynthetic rates and also it increases the water use efficiency of crops, hence increase in organic matter supplies to soils. Increase $\mathrm{CO}_{2}$ would tend to counteract adverse effects of temperature rise, such as increased night time respiration. Increases productivity is generally accompanied by more litter or crop residues, a greater total root mass and root exudates, increases mycorrhizal colonization and activity of other rhizosphere or soil microorganism, positive effect on $\mathrm{N}$ supply to crop. Increases microbial and root activity in the soil would entail higher $\mathrm{CO}_{2}$ partial pressure in soil air and $\mathrm{CO}_{2}$ activity in soil water, hence increased rates of plant nutrient release from weathering of soil mineral. Mycorrhizal activity would lead to better phosphate uptake. Increased production of root material (at similar temp) tends to raise soil organic matter content. Temporary immobilization and cycling of greater quantities of plant nutrients in the soil. Higher $\mathrm{C} / \mathrm{N}$ ratios under high $\mathrm{CO}_{2}$ condition cause slower remobilization of plant nutrients from the litter and uptake by the root.

\section{References}

Aon, M.A., Cabello, M.N., Sarena, D.E., Colaneri, A.C., Franco, M.G., Burgos, J.L., and Cortassa, S., 2001, I. Spatiotemporal patterns of soil microbial and enzymatic activities in agricultural soils. Appl. Soil Ecol., 18:239-254.

Bluemle, J.P., Sabel, J.M. and Karlén, W., 1999, Rate and magnitude of past global climate changes. Environ. Geosci., 6:63-75.

Blume, H.P., 2011, Global Climate Change Effects on Soils Bull. Georg. Natl. Acad. Sci., 5(2):106-112.

Brinkman, R. and Brammer, H., 1990. The influence of a changing climate in soil properties. In: Trans. 14th ISSS Congress, Kyoto. Pp. 283-287.

Brinkman, R., and Sombroek, W., 1999, Chapter 3. The effects of global change on soil conditions in relation to plant growth and food production. In: Bazzaz $\mathrm{F}$, Sombroek W (Eds) Global climate change and agricultural production. Food and Agriculture Organization of the United Nations and John Wiley and Sons Ltd., Rome, Italy. Accessed online from: http://www.fao.org. Accessed 15 Feb 2010.

Carter, R.M., 2007, The myth of dangerous human-caused climate change. In: Proceedings of the Australasian Institute of Mining \& Metallurgy New Leaders Conference, 2-3 May 2007, Brisbane. 6174.

Castro, H. F., Classen, T.A., Austin, E.E., Norby, R.J. and Schadt, C. W., 2009, Soil microbial community responses to multiple experimental climate change drivers. Appl. Environ. Microbiol., 76 (4): 999 - 1007.

Chou, W.W., Silver, W.L., Jackson, R.D., Thompson, A.W. and Diaz, A. B., 2008, The sensitivity of annual grassland carbon cycling to the quantity and timing of rainfall. Glob. Chang Biol., 14:1382-1394.

Cooney, C.M., 2010, The perception factor: Climate change gets personal. Environ. Health Perspect., 118(11):A484-A489.

Corfee-Morlot, J., Maslin, M. and Burgess, J., 2007, Global warming in the public sphere. Philos. Trans. R. Soc. London. Ser.A, 
365:2741-2776.

Dalal, R.C. and Moloney, D., 2000, Sustainability indicators of soil health and biodiversity. In: Hale P, Petrie A, Moloney D, Sattler P (eds) Management for sustainable ecosystems. Centre for Conservation Biology, Brisbane.101-108.

Davidson, E.A. and Janssens, I.A., 2006, Temperature sensitivity of soil carbon decomposition and feedbacks to climate change. Nature, 440:165-173.

DeVries, W. and Breeuwsma, A., 1987, The relationship between soil acidification and element cycling Water Air Soil Pollut. 35:293-310.

Dorodniko, M., Blagodatskaya, E., Blagodatsky, S., Marhan, S., Fangmeier, A. and Kuzyakov, Y., 2009, Stimulation of microbial extracellular enzyme activities by elevated $\mathrm{CO}_{2}$ depends on soil aggregate size. Glob.Change Biol., 15:1603-1614.

French, S., Levy-Booth, D., Samarajeewa, A., Shannon, K.E., Smith, J. and Trevors, J.T., 2009, Elevated temperatures and carbon dioxide concentrations: effects on selected microbial activities in temperate agricultural soils. World J. Microbiol. Biotechnol., 25:1887-1900.

Groffman, P.M., Hardy, J.P., Fisk, M.C., Fahey, T.J. and Driscoll, C.T., 2009, Climate variation and soil carbon and nitrogen cycling processes in a northern hardwood forest. Ecosystems, DOI: 10.1007/s10021009-9268-y.

Gregorich, E.G., Carter, M.R., Angers, D.A., Monreal, C.M. and Ellert, B.H., 1994, Towards a minimum data set to assess soil organic matter quality in agricultural soils. Can. J. Soil Sci., 74:367-385.

Haynes, R.J., 2008, Soil organic matter quality and the size and activity of the microbial biomass: their significance to the quality of agricultural soils. In: Huang Q, Huang PM, Violante A (eds) Soil mineralmicrobe-organic interactions: theories and applications. Springer, Berlin., 201-230.

Idowu, O.J., Van Es, H.M., Abawi, G.S., Wolfe, D.W., Schindelbeck, R.R., Moebius-Clune, B.N. and Gugino,

B.K., 2009, Use of an integrative soil health test for evaluation of soil management impacts.
Renew Agric. Food Syst., 24:214-224.

IPCC. 2007. Climate change 2007 synthesis report. In: R.K. Pachauri and A. Reisinger, editors, Working group contributions to the fourth assessment report of the intergovernmental panel on climate change.

Cambridge Univ. Press, Cambridge, UK., 23-73.

Jastrow, J. R., Miller, M., Matamala, R., Norby, R.J., Boutton, T.W., Rice, C.W. and Owensby., C.E., 2005, Elevated atmospheric carbon dioxide increases soil carbon. Global Change Biol., 11: 2057 2064.

Karlen, D.L, Doran, J.W., Andrews, S.S., Wienhold, B.J., 2003, Soil Quality Humankinds' foundation for survival. J Soil Water Conserv., 58:171-179.

Kibblewhite, M.G., Ritz, K. and Swift, M.J., 2008, Soil health in agricultural systems.. Philos. Trans. R. Soc., 363:685-701.

Kinyangi, J., 2007, Soil health and soil quality: a review. Draft publication. Available on: http://

www.cornell.edu.org; Accessed on: www.worldaginfo.org. Accessed 15 Feb 2010.

Kumar, M. and Swarup, A., 2012, Impact of elevated atmospheric $\mathrm{CO}_{2}$ and temperature on plant available phosphorus in soil - Assessment using ${ }^{32} \mathrm{P}$ tracer technique. J. Indian Soc. Soil Sci., 60 (4): $312-316$.

Kutílek, M., 2011, Soils and climate change. Soil Tillage Res., 117:1-7.

Lal, R., 1994, Soil Processes and Greenhouse Effect. CRC Lewis Publishers, Boca Raton. 440.

McCarthy, J.O., Canziani, and Leary, N., et al., (eds.) 2001, Climate change 2001: Impacts, adaption, and vulnerability.

Contribution of working Group II to the Third Assessment Report of the Intergovernmental Panel on Climate Change. Univ. Press, Cambridge.

Nuttall, J.G., 2007, Climate change - identifying the impacts on soil and soil health. Department of Primary Industries, Future Farming Systems Research Division, Victoria.

Pastor, J. and Post, W.M., 1988, Response of 
northern forests to $\mathrm{CO}_{2}$ induced climate change. Nature, 334: 55 - 58.

Pregitzer, K.S., Burton, A.J., King, J.S. and Zak, D.R., 2008, Soil respiration, root biomass, and root turnover following long-term exposure of northern forests to elevated atmospheric $\mathrm{CO}_{2}$ and tropospheric $\mathrm{O}_{3}$., New Phytologist., 180: 153-161.

Prior, S. A., Runion, B.G., Torbert, H.A. and Roger, H. H., 2004, Elevated atmospheric $\mathrm{CO}_{2}$ in agro-ecosystems: soil physical properties. Soil Sci., 169(6): 434-439.

Reth, S., Reichstein, M. and Falge, E., 2005, The effect of soil water content, soil temperature, soil $\mathrm{pH}$ - value and root mass on soil $\mathrm{CO}_{2}$ efflux. Plant Soil, 268:21-33.

Reynolds, W.D., Drury, C.F., Tan, C.S., Fox, C.A. and Yang, X.M., 2009, Use of indicators and pore volume- function characteristics to quantify soil physical quality. Geoderma 152:252-263.

Rinnan, R., Michelsen, A., Bååth, E. and Jonasson, S., 2007, Fifteen years of climate change manipulations alter soil microbial community,es in a subarctic heath ecosystem. Glob Change Biol., 13:28-39.

Rounsevell, M. D. A. and Loveland, R. J., (eds.) 1994, Soil Responses to Climate Change, NATO ASI Series I: Global Environmental Change. Springer-Verlag. London., 23: 312.

Ruiz, G.R., Ochoa, V., Vinegla, B., Hinojosa, M.B., Pena-Santiago, R., Liébanas, G.,
Linares, J.C. and Carreira, J.A., 2009, Soil enzymes, nematode community and selected physico-chemical properties as soil quality indicators in organic and conventional olive-oil farming: influence of seasonality and site features. Appl. Soil Ecol., 41:305-314.

Scharpenseel, H. W., Schomaker, M. \& Ayoub, A., (eds.) 1990, Soils on a Warmer Earth. Elsevier Amsterdam, 274.

Shakiba, A., 2000, The potential effects of global warming on Soil carbon pool. Remote sensing and GIS Dept. Earth science faculty, Shahid Beheshti Univ. Evin, Tehran, Iran.312-317.

Smith, J.L., Halvorson, J.J. and Bolton, J.R.H., 2002, Soil properties and Microbial activity across a $500 \mathrm{~m}$ elevation gradient in a semiarid environment. Soil Biol \& Biochem., 34:1749-1757.

Stenberg, B., 1999, Monitoring soil quality of arable land: microbiological indicators. Acta Agriculturae Scandinavica., Sect. B. Soil Plant Sci., 49:1-24.

Weil, R.R. and Magdoff, F., 2004, Significance of soil organic matter to soil quality and health. In: Weil RR, Magdoff F (eds) Soil organic matter in sustainable agriculture. CRC press, Florida. 1-43.

Wixon, D.L., and Balser, T.C., 2009, Complexity, climate change and soil carbon: a systems approach to microbial temperature response. Syst. Res. Behav. Sci., 26:601620.

\section{How to cite this article:}

Anjali, M.C., and Dhananjaya, B.C. 2019. Effect of Climate Change on Soil Chemical and Biological Properties- A Review. Int.J.Curr.Microbiol.App.Sci. 8(02): 1502-1512. doi: https://doi.org/10.20546/ijcmas.2019.802.174 